\title{
Front Matter: Volume 11828
}

, "Front Matter: Volume 11828," Proc. SPIE 11828, ODS 2021: Industrial Optical Devices and Systems, 1182801 (16 September 2021); doi: $10.1117 / 12.2606279$

SPIE Event: SPIE Optical Engineering + Applications, 2021, San Diego, California, SPIE. United States 


\title{
PROCEEDINGS OF SPIE
}

\section{ODS 2021: Industrial Optical Devices and Systems}

\author{
Ryuichi Katayama \\ Yuzuru Takashima \\ Editors
}

1-5 August 2021

San Diego, California, United States

Sponsored and Published by

SPIE 
The papers in this volume were part of the technical conference cited on the cover and title page. Papers were selected and subject to review by the editors and conference program committee. Some conference presentations may not be available for publication. Additional papers and presentation recordings may be available online in the SPIE Digital Library at SPIEDigitalLibrary.org.

The papers reflect the work and thoughts of the authors and are published herein as submitted. The publisher is not responsible for the validity of the information or for any outcomes resulting from reliance thereon.

Please use the following format to cite material from these proceedings:

Author(s), "Title of Paper," in ODS 2021: Industrial Optical Devices and Systems, edited by Ryuichi Katayama, Yuzuru Takashima, Proc. of SPIE 11828, Seven-digit Article CID Number (DD/MM/YYYY); (DOI URL).

ISSN: 0277-786X

ISSN: 1996-756X (electronic)

ISBN: 9781510644946

ISBN: 9781510644953 (electronic)

Published by

SPIE

P.O. Box 10, Bellingham, Washington 98227-0010 USA

Telephone +1 3606763290 (Pacific Time)

SPIE.org

Copyright @ 2021 Society of Photo-Optical Instrumentation Engineers (SPIE).

Copying of material in this book for internal or personal use, or for the internal or personal use of specific clients, beyond the fair use provisions granted by the U.S. Copyright Law is authorized by SPIE subject to payment of fees. To obtain permission to use and share articles in this volume, visit Copyright Clearance Center at copyright.com. Other copying for republication, resale, advertising or promotion, or any form of systematic or multiple reproduction of any material in this book is prohibited except with permission in writing from the publisher.

Printed in the United States of America by Curran Associates, Inc., under license from SPIE.

Publication of record for individual papers is online in the SPIE Digital Library.

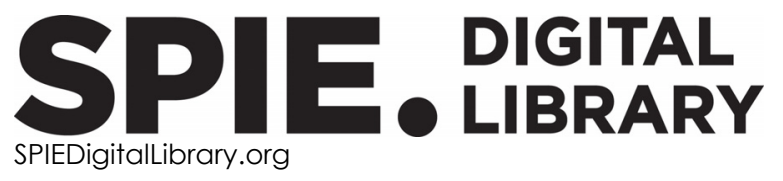

Paper Numbering: A unique citation identifier (CID) number is assigned to each article in the Proceedings of SPIE at the time of publication. Utilization of CIDs allows articles to be fully citable as soon as they are published online, and connects the same identifier to all online and print versions of the publication. SPIE uses a seven-digit CID article numbering system structured as follows:

- The first five digits correspond to the SPIE volume number.

- The last two digits indicate publication order within the volume using a Base 36 numbering system employing both numerals and letters. These two-number sets start with $00,01,02,03,04$, 05, 06, 07, 08, 09, 0A, OB ... 0Z, followed by 10-1Z, 20-2Z, etc. The CID Number appears on each page of the manuscript. 


\section{Contents}

MEASUREMENT AND SENSING

$1182802 \quad$ Highly reconfigurable and integrated optical time-domain reflectometer featuring high spatial resolution for short-reach and long-haul networks [1 1828-11]

$1182805 \quad$ Automated 3D geometrical measurement system for mobile and large-scale conical workpiece based on laser scanning technologies [1 1828-12]

\section{NEW TECHNOLOGIES}

1182806 Curved waveguide combiner for HUD/AR [1 1828-14]

$1182807 \quad$ Enhancing the multi-tone continuous-wave lidar with phase detection [1 1828-15]

1182808 An optical computing chip executing complex-valued neural network and its on-chip training (Invited Paper) [1 1828-13]

$1182809 \quad$ Analysis of diffraction efficiency of TI-PLM and its potential in beam steering [1 1828-16]

\section{OPTICAL DATA STORAGE}

11828 OC Media noise suppression by multimodal optical disc readout [1 1828-3]

11828 OD Investigation on how to excite a desired eigenmode selectively in the ring-resonator-type device for heat-assisted magnetic recording [11828-4] 
Proc. of SPIE Vol. 11828 1182801-4

\section{Downloaded From: https://www.spiedigitallibrary.org/conference-proceedings-of-spie on 26 Apr 2023
Terms of Use: https://www.spiedigitallibrary.org/terms-of-use}

